\title{
TEACHING TECHNOLOGY: FROM KNOWING TO FEELING ENHANCING EMOTIONAL AND CONTENT ACQUISITION PERFORMANCE THROUGH GARDNER'S MULTIPLE INTELLIGENCES THEORY IN TECHNOLOGY AND DESIGN LESSONS
}

\author{
Jesus Sanchez-Martin*iD, Garcia J. Alvarez-Gragera ${ }^{(D)}$, \\ Maria Antonia Davila-Acedo (D), Vicente Mellado (iD \\ Department of Science and Mathematics Education, University of Extremadura. Faculty of Education \\ (Spain) \\ *Corresponding author: jsanmar@,unex.es, gjalvarezg@gmail.com, mdavilaacedo@unex.es, vmellado@unex.es
}

Received September 2016

Accepted November 2016

\section{Abstract}

Gardner's Multiple Intelligences Theory (MIT) can be a cognitive and emotional improvement if is taken into account in the standard development of the Technology lessons. This work presents a preliminary evaluation of the performance enhancement in two concomitant aspects: contents acquisition and emotional yield. The study was made on up to 150 students with ages of 12-13 years old. The control group was submitted to traditional transmission-reception lessons, whereas the experimental one was submitted to novel educational techniques that included specific activities which took into account the different intelligences styles (IS) inside the classroom. The results clearly depicted that both studied variables underwent a statistical significant enhancement through the application of the MIT-based educational method.

Keywords - Technology education, Emotions, Multiple intelligences theory. 


\section{Introduction}

It is not a secret for teachers and educators that emotions and feelings must be taken into account in the teaching-learning process, because emotional mechanisms play a vital role in how we acquire new knowledges and how we face the learning phenomenon. In fact, relevant educational researchers have underlined the relevance of such elements: Hargreaves (1998) set out that emotions are at the heart of education (pp. 558) and Otero (2006) notes that there is no human action without an emotion that substantiates it and makes it possible. However, the study of emotions and feelings was seen as being far removed from education for many years, and even more so from the teaching and learning of specific school content (Brígido, Borrachero, Bermejo \& Mellado, 2013; Álvarez \& Canal, 2013). In addition, Technology contents are even more distant from these considerations, that are recently inserted in the Science Education Corpus (Black \& Atkin, 2005).

For anyone that had act as a teacher, it is obvious that emotions and feelings must be included in the set of variables that should be handled by the educator for improving the development of learning and it is today recognized that the cognitive configures the affective, and vice versa. Consequently, the idea of teaching and learning as an emotional practice in which cognitive and affective processes take part is fully accepted (Brígido, Couso, Gutiérrez \& Mellado, 2013; Shapiro, 2010).

But what is an emotion? There are a variety of taxonomies for the affective domain, emotions, and feelings. For Dos Santos and Mortimer (2003), the affective is more general, and subsumes emotions, feelings, and moods. Many authors concur that emotions are the organism's automatic responses to external stimuli, whereas feelings are more permanent. In the present study, we shall be referring primarily to the emotions, although sometimes we shall refer generically to the affective dimension. Of the many definitions of emotions, we adopt that put forward by Bisquerra (2001):

Emotions are reactions to the information we receive in our relationships in the environment. The intensity of the reaction depends on subjective assessments that we make of how this information will affect our well-being. These subjective assessments will involve prior knowledge, beliefs, personal objectives, perception of a challenging environment, etc. An emotion depends on what is important for us.

Despite this general definition, there are different conceptions of emotions from one culture to another, and even these conceptions can change over time within the same culture, so that the 
existence of various alternative classifications may well be justifiable. Damasio (2010) classifies emotions as primary or basic, background, and social. Even from a neural, physicist point of view, Chai, Woo, Rizon and Tan (2010) classified emotions into five basic groups: Anger, Sad, Surprise, Happy, and Neutral. But the classification which comes closest to the nature of the current study is that which distinguishes between positive, negative and neutral emotions (Bisquerra, 2009; Brígido, Couso et al., 2013).

According to Littledyke (2008), emotions and affective domain must be included in the general engagement to science education. It is clear and known that each student feels in a different way if he/she perceives success or failure. Positive emotions will increase the academic efforts and the self-confidence, while no success appreciation would lead him/her to scholar drop (Weiner, 1986). It is remarkable that there are no totally negative emotions since anxiety could be a motivational force, but it could also block the student, even within adults (Goleman, 1996). Hence, a student can be blocked if facing emotional situations such as frustration, wrath or impotency inside or outside the scholar class. As Vázquez and Manassero (2007) pointed out, positive emotional states favor learning, while negative emotional states severely limit the ability to learn.

From theoretical framework of conceptual change and pupils' alternative ideas, Pintrich, Marx and Boyle (1993) question cold change, and argue for the importance of motivation and the emotions as determinants in learning. Positive emotional states favor learning, while negative emotional states severely limit the ability to learn (Vázquez \& Manassero, 2007). Conceptual change is therefore both cognitive and affective (Thagard, 2009) and teachers who ignore the affective aspects of learning may limit their pupils' conceptual change (Duit, Treagust \& Widodo, 2008). The relevance of emotions as activators of learning process has been poorly taken into account and almost no academic literature is found in the field of Technology education in Secondary School (Hill \& Smith, 1998). Previous research indicated the need for analyzing the emotions by distinguishing the different subjects of science and technology (Van Der Hoeven Kraft, Srogi, Husman, Semken \& Fuhrmman, 2011; Vázquez \& Manassero, 2007). Other studies show that secondary pupils have positive attitudes and emotions towards Biology and Geology and negative ones towards Physics and Chemistry (Borrachero Brígido, Gomez, Bermejo \& Mellado, 2011; Brígido, Borrachero et al., 2013; Marbá-Tallada \& Márquez, 2010). It is also remarkable the fact that the active assumption of the technology at emotional level is absolutely essential in the integration of these contents and, consequently, a technology learned under negative feelings will be unuseful for learners, either young or adult pupils (Straub, 2009). 
Gardner's Multiple Intelligences Theory (MIT) arose more than 30 years ago (Gardner, 1983a,b) and does not limit intelligence to its purely cognitive facet (Gardner, 1995), but takes account of its affective and emotional sides. Despite of it age, it is difficult to find specific educative applications of such theory. The Intelligence Style (IS) of each subject is obviously relevant for designing the different learning strategies, but perhaps a twist on this could be the identification of the emotional performance of each subject according to his/her IS. This information will be useful for complementing the teaching process by considering the emotional response and consequently giving the student an opportunity to improve his/her academic performance. This was also reported by Gardner (1989) in the early years of the Multiple Intelligences Theory (MIT) and this fact has been confirmed by other researchers (Al-Balhan, 2006).

Since Gardner set out his theory, many studies have been focused on the estimation of the prevalent thinking style (Furnham, 2001; Furnham, Wytykowska \& Petrides, 2005), but there exists a general consensus inside the scientific community on the adoption of different mechanisms for measuring the intelligence of the individuals, mainly by considering this measure as a way of enhancing one's own development rather than imposing certain limits to either personal and academic growth (Almeida, Prieto, Ferreira, Bermejo, Ferrando \& Ferrandiz, 2010).

The use of MIT inside the academic field as a teaching path for enhancing student's capabilities have been previously reported in some published papers with general purposes (Armstrong, 2009; Akkuzu \& Akçy, 2011) or particular ones, that is, focusing the science and mathematics education (Sulaiman, Abdurahman \& Rahim, 2010; Karamikabir, 2012).

Some authors have pointed out the relevance of including MIT in the general orientation of academic Science and Technology lessons (McKenczie, 2005). In the same researching line, the current work has the objective of identifying and measuring the eventual good effect of including MIT-based activities in the development of a specific topic inside the Technology lessons. We have implemented a Didactic Unit that involves up to 9 activities, each one oriented for each IS. The aim of this work is to evaluate the double performance of such teaching methodology: cognitive and emotional. In other words, our working question is: does these strategies improve the emotional and cognitive yield of the students? Additionally, since we have identified the IS of the students, we can see if this teaching strategy benefits even more to some IS. 


\section{Methodology}

\subsection{The intervention and the teaching methodologies}

It is already known that different teaching methodologies lead to better learning results. Fried (2001) presents an experience where a math teacher explains this:

This a trait that I now bring into my teaching. When I am preparing my lessons, I always try to have three or four different approaches -visual forms, abstract forms, hands-on forms- to find some way of connecting with each child, just like when I was helping out in eighth grade. To me, the principles of mathematics apply very much to the principles of life. (pp. 161)

So it is not a secret variety in class activities enhances the comprehension of difficult concepts. But our aim is to check out the applicability of MIT to Technology education, that is, how to improve the teaching-learning process of Technology taking into account Gardner's theory.

The comparison between two groups is based on designing an intervention plan that involves MIT principles. The control group (73 subjects) was submitted to traditional magistral expositive lessons: the teacher explained the technology concepts, the students take down their notes, and eventually the class carried out a hands-on activity in laboratory. Please be aware that this traditional method is not out from MIT assumptions: when we put our interest in mathematical problem solving we are favoring logical-mathematical thinking style; when we show the technology contents only by words or we make the students to write down, we are favoring linguistic prevalent intelligence, and so on.

The intervention group (87 subjects) was submitted instead to a complete set of activities, nine in total. Each activity develops some aspects of the technology topic, paying special attention to methods that presumably will be friendly to each thinking style. For example, musical prevalent intelligence has been usually considered out of technology issues and with a low performance (Álvarez-Gragera, Sánchez-Martín, Dávila-Acedo \& Mellado, 2016). Inside the intervention group, students with musical prevalent intelligence will be able to carry out at least one activity that surely will like them: finding out a song about electromagnetic field or even composing it, etc. This is not the only activity they will do (8 more are planned), but we have designed the educative intervention taking this preferences into account. 


\subsection{The questionnaires and the data collection}

The study universe involved 157 subjects, splitted in two groups (control and experimental one). $53 \%$ of them belonged to the experimental group whereas $47 \%$ was assigned to the control one. The study involved 69 (44\%) boys and 89 (56\%) girls, and up to 4 Secondary Schools were implied in the work. All of them belonged to similar rural areas at Extremadura region, in Spain. Control group was submitted to traditional teaching procedures (magistral lessons and exposition by the teacher), while the experimental group received a more innovative teaching strategy, including the development of a Didactic Unit that was designed with up to 9 different activities, one for each IS.

Since the current research merges two aspects of the teaching-learning process (the emotional yield and the content acquisition), three elements have been taken into account for data collection:

The tool for measuring the prevalent IS (Test 1) was adapted from previous works (Armstrong, 2009) which were mainly based on Gardner's first approaches (Gardner, 1983a,b, 1991). The version designed by Giorgis (Giorgis, 2007) was used since it shows a wide acceptation amongst the Spanish audience (Barrientos Jiménez, Mattza Díaz, Vildoso Villegas \& Carola Sanchez, 2009) and consequently was appropriately checked its validity and robusticity. In it the student must score in a $0-5$ scale of agreement a total of 32 questions about the way he or she learns in an easier way. The analysis of such items should lead us to assign him/her a predominant IS.

\begin{tabular}{|l|l|}
\hline & SCORING \\
\hline I can easily express myself writing & \\
\hline I can easily follow a reading or a written article & \\
\hline I have a broad vocabulary & \\
\hline I am good in explaining things to other classmate & \\
\hline I like working with numbers & \\
\hline I enjoy solving problems & \\
\hline I like carrying out a homework in a logical and tidy form & \\
\hline I can easily work with scientific arguments & \\
\hline I can easily understand a map & \\
\hline I can easily assemble a puzzle & \\
\hline I can easily retain an image in my mind & \\
\hline I find useful understanding diagrams and graphs & \\
\hline I can easily remember a melody & \\
\hline I can play musical instruments & \\
\hline I can differentiate instruments in an orchestral piece & \\
\hline I enjoy listening to music or composing & \\
\hline I enjoy working with my hands & \\
\hline It is frustrating for me stay sitting for a long time & \\
\hline I enjoy physical activities and sport & \\
\hline I prefer learning in an active way rather than reading or paying attention in class & \\
\hline
\end{tabular}




\begin{tabular}{|l|l|}
\hline & SCORING \\
\hline I enjoy the flora, fauna and natural phenomena & \\
\hline I like to collect plants, insects, rocks... & \\
\hline I am good at discovering things in nature & \\
\hline I am aware of protecting the environment & \\
\hline I like working in team & \\
\hline I get on well with everyone & \\
\hline I enjoy to get in relationship with other people & \\
\hline I have a lot of conviction power & \\
\hline I need no one to motivate me to do things & \\
\hline I am good at controlling my state of mind & \\
\hline I prefer working alone & \\
\hline I am aware of my behavior and how it affects to others & \\
\hline
\end{tabular}

Test 1. Questionnaire for evaluating the prevalent intelligence style. Participant must score each item from 0 to 5.

Source: Giorgis, 2007

In the case of the emotional score, the questionnaire was made ad hoc (Test 2). In it, students were asked to write down what emotions feel when doing a particular task. For example, when asked about the feelings when studying the effects of electricity, a student could answer 'surprise'. The answer choices, regarding the involved emotions, were Surprise, Happiness, Sadness, Wrath and Fear. Each emotion has a specific score from 10 (Surprise) to 2 (Fear). The global score gave us the positive emotional score for each student. A maximum of 100 points can be obtained. This scoring is built up according to some recent studies and statements. E.g. Gianotti (2015) declared to a national newspaper that The maximum satisfaction for a scientist is surprise. In the academic field, it is well-known the link between surprise and exploration aim (Plutchik, 2001), that was recently revisited by Choliz (2005). Experimentally, Conejo, Garcia-Vinas, Gaston and Barros (2015) has proved that technology-assisted gaming is positive for enhancing the knowledge acquisition in science and for promoting the scientific skills development through surprise and entertainment activities. The validation of this test (since it was built up by us) was checked according to Cronbach's alpha level (SPSS, 2005) and it was equal to 0.815 for both pretest and post-test values. This value is high enough for considering this tool consistent, coherent and robust. 


\begin{tabular}{|c|c|c|c|}
\hline SYLLABUS UNIT & I feel & Because ... & And I solve it... \\
\hline When they order me to use the drill... & Fear & $\begin{array}{l}\text { Classmates will } \\
\text { laugh of me }\end{array}$ & $\begin{array}{l}\text { Allowing my classmates to do it } \\
\text { instead of me }\end{array}$ \\
\hline \multicolumn{4}{|l|}{ SYLLABUS UNIT 1} \\
\hline \multicolumn{4}{|l|}{$\begin{array}{l}\text { When your classmate order you to do a task } \\
\text { for solving a problem... }\end{array}$} \\
\hline \multicolumn{4}{|l|}{$\begin{array}{l}\text { When they ask you to cooperate in the } \\
\text { resolution of a problem... }\end{array}$} \\
\hline \multicolumn{4}{|l|}{$\begin{array}{l}\text { When they ask you to contribute ideas about a } \\
\text { problem... }\end{array}$} \\
\hline \multicolumn{4}{|l|}{$\begin{array}{l}\text { When they ask you to respect the safety rules } \\
\text { in the atelier... }\end{array}$} \\
\hline \multicolumn{4}{|l|}{ SYLLABUS UNIT 2} \\
\hline \multicolumn{4}{|l|}{$\begin{array}{l}\text { When they ask you to write down documents } \\
\text { with a computer... }\end{array}$} \\
\hline \multicolumn{4}{|l|}{$\begin{array}{l}\text { When they talk to you about the operating } \\
\text { systems... }\end{array}$} \\
\hline \multicolumn{4}{|l|}{$\begin{array}{l}\text { When you store or copy documents in your } \\
\text { computer such as photos... }\end{array}$} \\
\hline \multicolumn{4}{|l|}{$\begin{array}{l}\text { When you present texts, photos, drawings or } \\
\text { videos with the computer... }\end{array}$} \\
\hline \multicolumn{4}{|l|}{ SYLLABUS UNIT 3} \\
\hline \multicolumn{4}{|l|}{$\begin{array}{l}\text { When you work with wood, cork or other } \\
\text { materials at the workshop... }\end{array}$} \\
\hline \multicolumn{4}{|l|}{$\begin{array}{l}\text { When you use the machines and tools such as } \\
\text { drill, saw or silicone gun... }\end{array}$} \\
\hline \multicolumn{4}{|l|}{$\begin{array}{l}\text { When you learn different techniques for } \\
\text { working onto several materials }\end{array}$} \\
\hline \multicolumn{4}{|l|}{$\begin{array}{l}\text { When you are said to use the minimum } \\
\text { amount of materials for not spending or } \\
\text { polluting the environment... }\end{array}$} \\
\hline \multicolumn{4}{|l|}{ SYLLABUS UNIT 4} \\
\hline \multicolumn{4}{|l|}{$\begin{array}{l}\text { When you have to draw with a rule, set-square } \\
\text { and compass... }\end{array}$} \\
\hline \multicolumn{4}{|l|}{ When you must draw views and perspective... } \\
\hline \multicolumn{4}{|l|}{ When they ask you to interpret a scheme } \\
\hline \multicolumn{4}{|l|}{$\begin{array}{l}\text { When you are asked to draw an object } \\
\text { perspective }\end{array}$} \\
\hline \multicolumn{4}{|l|}{ SYLLABUS UNIT 5} \\
\hline \multicolumn{4}{|l|}{$\begin{array}{l}\text { When you study the strengths such as flexion, } \\
\text { traction and compression... }\end{array}$} \\
\hline \multicolumn{4}{|l|}{ When you build structures at the atelier... } \\
\hline \multicolumn{4}{|l|}{$\begin{array}{l}\text { When you are asked to identify an element of } \\
\text { a structure and indicate the effort that it } \\
\text { performs... }\end{array}$} \\
\hline \multicolumn{4}{|l|}{$\begin{array}{l}\text { When you study how to improve a structure } \\
\text { with triangulations or by lowering its gravity } \\
\text { center... }\end{array}$} \\
\hline \multicolumn{4}{|l|}{ SYLLABUS UNIT 6} \\
\hline \multicolumn{4}{|l|}{$\begin{array}{l}\text { When you study concepts such as intensity, } \\
\text { voltage or resistances... }\end{array}$} \\
\hline \multicolumn{4}{|l|}{ When you calculate serial or parallel circuits... } \\
\hline \multicolumn{4}{|l|}{$\begin{array}{l}\text { When you build up electrical circuits within a } \\
\text { technical project... }\end{array}$} \\
\hline $\begin{array}{l}\text { When you study the benefits and harmful } \\
\text { effects of the electricity... }\end{array}$ & & & \\
\hline
\end{tabular}




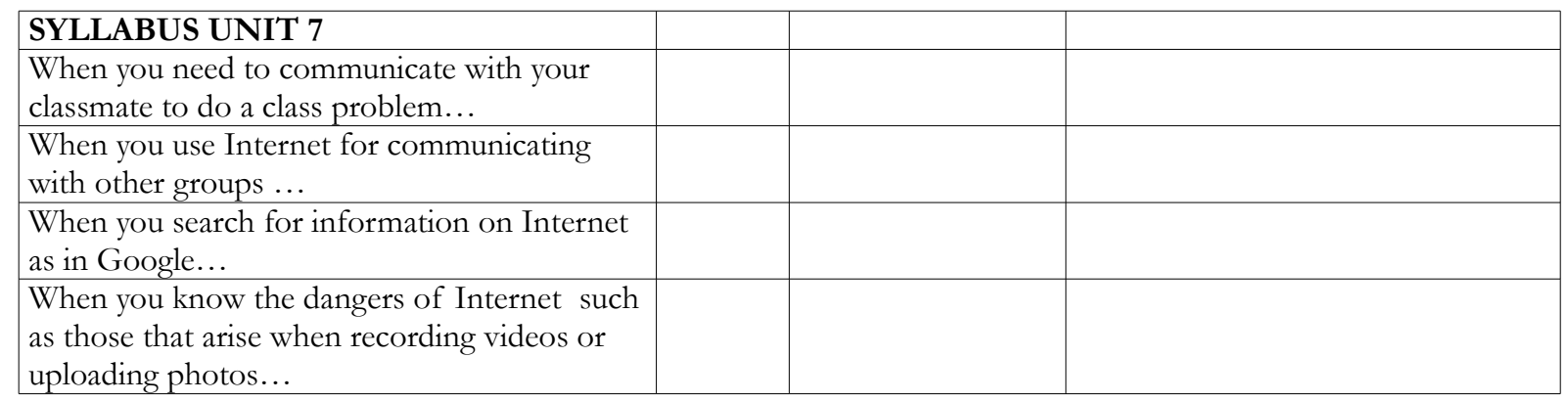

Test 2. Questionnaire for evaluating the emotions of the students. Participant must consign in the table the situations given in class and indicate what emotion is prevalent (Anger, Sadness, Fear, Happiness, Satisfaction, Surprise,

Boredom or Sham), the reason for that feeling and the method for overcoming.

Finally, the contents acquisition test was the specific evaluation exam of the topic. The maximum score that can be obtained here is again 100 .

Each test was made before and after the teaching intervention, and the contrast was done on an Experimental group and on a Control group, so the differences between them revealed the efficiency of the teaching methodology.

\subsection{Data analysis}

Data analysis was carried out by using SPSS package (SPSS, 2005). For the full analysis, several concomitant statistical test were performed subsequently:

Firstly, a comparison between the two groups (Experimental and Control) was made regarding the pre-test results through t-Student statistical test. This will give us the indistinguishability and the homogeneity of the universe.

Then, pre and post-test results are compared in each group for confirming the effect of the teaching intervention. In other words, there exists some kind of action on the students' emotions and knowledge whatever the teacher does.

Since we aim to identify which methodology is the best one for improving the emotional and the content acquisition yield, post-test results were compared between the two groups globally, that is, without segmenting the analysis by the IS of each student. For this, a one-way ANOVA test was carried out. 
Finally, we would like to identify which IS is more favored with this kind of teaching methodology (if any). To evaluate this, a one-way ANOVA analysis was carried out on the segmented data (according to IS).

Technically, the statistical analysis results were contrasted with an $\alpha=0.5$ (confidence p-value of $0.05)$.

\section{Discussion and results}

The empirical confirmation of a higher emotional and cognitive scoring if MIT is taken into account is the expected result of the current work. This should also be useful for supporting wider theories, such as the one reported by Barrington (2004). This author pointed out the goodness of MIT as a tool for making the School even more inclusive, stimulating the adaptation of those students with more academic difficulties. Additionally, the variation in the instruction methodology (making the lessons dynamic and in some sense different for each student) would help in the acquisition of several desired scientific, academic and citizen skills (Li \& Tsai, 2013). In addition, we found many literacy evidences on the relevance of stimulating creativity and problem-facing activities inside the technology lessons. We agree with Lewis (2009) when he stated out that:

It is evident that the subject (technology) provides a variety of avenues by which children can employ cognitive resources not ordinarily taxed by the academic curriculum. Design and problem solving activities challenge children and teachers alike.

\subsection{Validity of the study universe. Indistinguishability of mean score}

As an initial approach to the data results, a preliminary test for confirming the validity of the whole study must be carried out on the data set. This consists of the confirmation of equal variances (Levene's statistics) and a one-way ANOVA statistical test for accepting the hypothesis of indistinguishability. This means the variable 'Group' (Empirical or Control) does not affect to the preliminary value of the mean emotional or knowledge score and consequently both groups are undistinguishable interms of previous emotions or knowledge content.

The statistical results of this first step confirmed our working hypothesis. Levene's statistical reached 0.05 ( $\mathrm{p}$-value of 0.82 ) in the case of knowledge content and 1.1 ( $\mathrm{p}$-value of 0.29 ) in the 
case of emotional score. This confirms equal variances. Additionally, ANOVA test gave a p-value of 0.08 for the first analysis (knowledge) and 0.85 for the second one (emotional rate). Both of them are over 0.05 , the significativity limit, so the preliminary hypothesis of indistinguishability can be statistically accepted. Graphically, Figure 1 presents these results. As clearly depicted, error bars (confidence interval of 95\%) are, in both cases, overlapped. Both groups are consequently homogeneous for the intervention analysis.

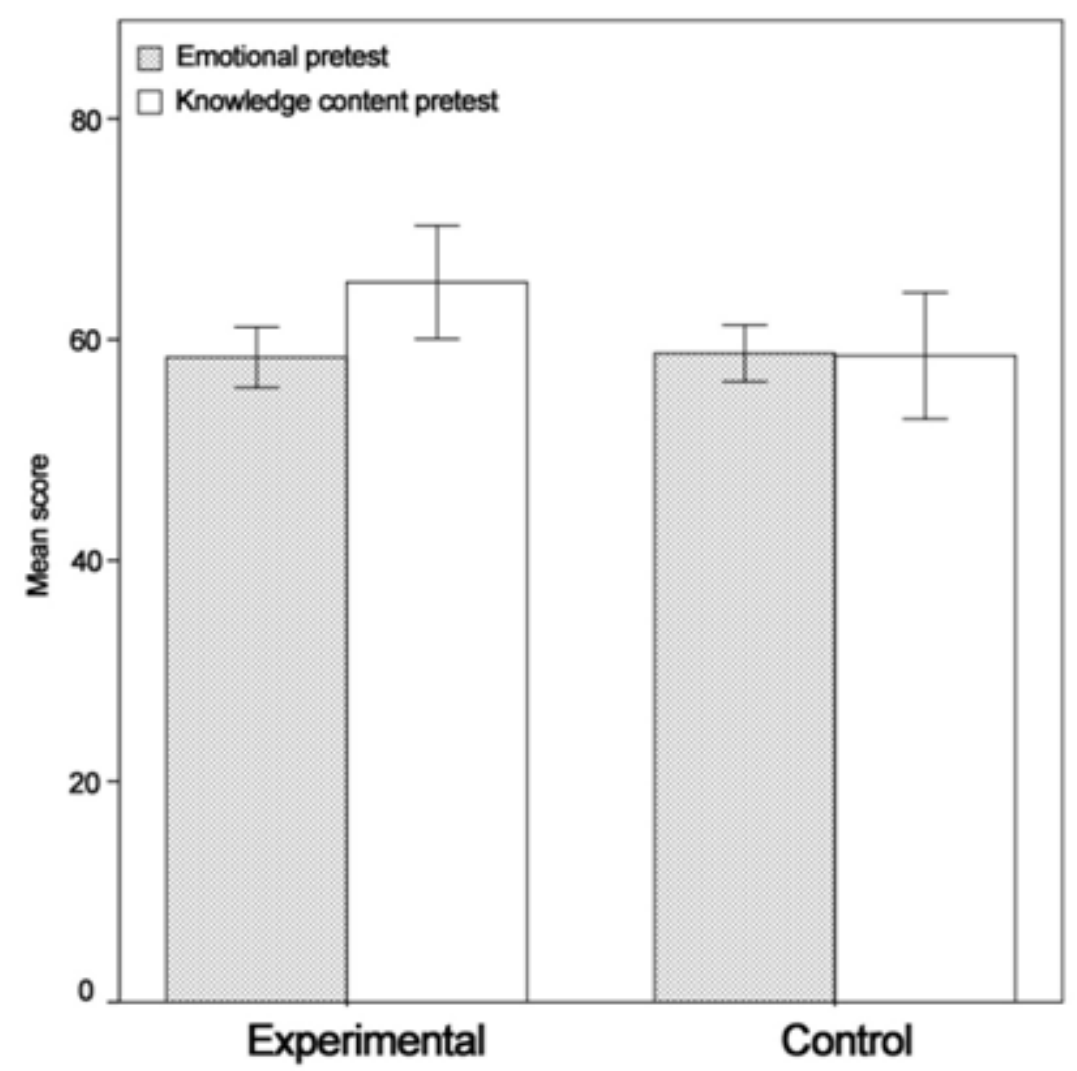

Figure 1. Mean score for emotional and knowledge content in pretest evaluation for Experimental and Control group. Confidence interval for error bars of $95 \%$ 


\subsection{Validity of every educative intervention}

The second confirmation we attempt to reach is the assumption that both educative interventions (the traditional one and the MIT-based one) do effect on the emotional and knowledge acquisition yield of the students. This can be observed through a t-Student statistical test, which will give us if there exists any statistically significant difference between the scores obtained by the pre-test and those obtained by the post-tests. Table 1 presents the analytical results. The statistical significance of $\mathrm{t}$-Student test was given by a $\mathrm{p}$-value of 0.00 , so the differences due to the educative intervention (both kinds) are evident.

\begin{tabular}{|l|r|r|r|r|}
\hline \multicolumn{1}{|c|}{ Group } & Emotional pre-test & Emotional post-test & Knowledge pre-test & Knowledge post-test \\
\hline Control & 58.74 & 54.74 & 58.54 & 61.56 \\
\hline Experimental & 58.39 & 63.28 & 65.18 & 69.50 \\
\hline
\end{tabular}

Table 1. Mean scores for emotional and knowledge acquisition yield according to pre-test and post-test results

\subsection{Prevalence of MIT-based teaching methodology}

Although both teaching methodologies have been checked in terms of effect on the students' emotional and cognitive yield (being favorable), as the study universe was confirmed to be homogeneous, the post-test results can be compared in order to stablish which teaching strategy leads to a better result, either in emotional and cognitive aspects. This can be easily carried out through a one-way ANOVA test where we can compare the results of both post-test in the control group and in the experimental one. The analytical numerical results can be observed again in table 1. ANOVA test also gives us the statistical data of a p-value of 0.00 for emotional performance and 0.34 for content acquisition (cognitive yield). Both p-values are under the significativity limit of 0.05 , so one can affirm with a $95 \%$ of confidence that there exists differences between the two groups in terms of emotional and cognitive yield, being more favorable in the experimental group. In other words, the results obtained in the experimental group by using the MIT-based teaching strategy are better than those obtained in the control group with the traditional exposition methodology. The comparison can be also seen graphically in Figure 2. 


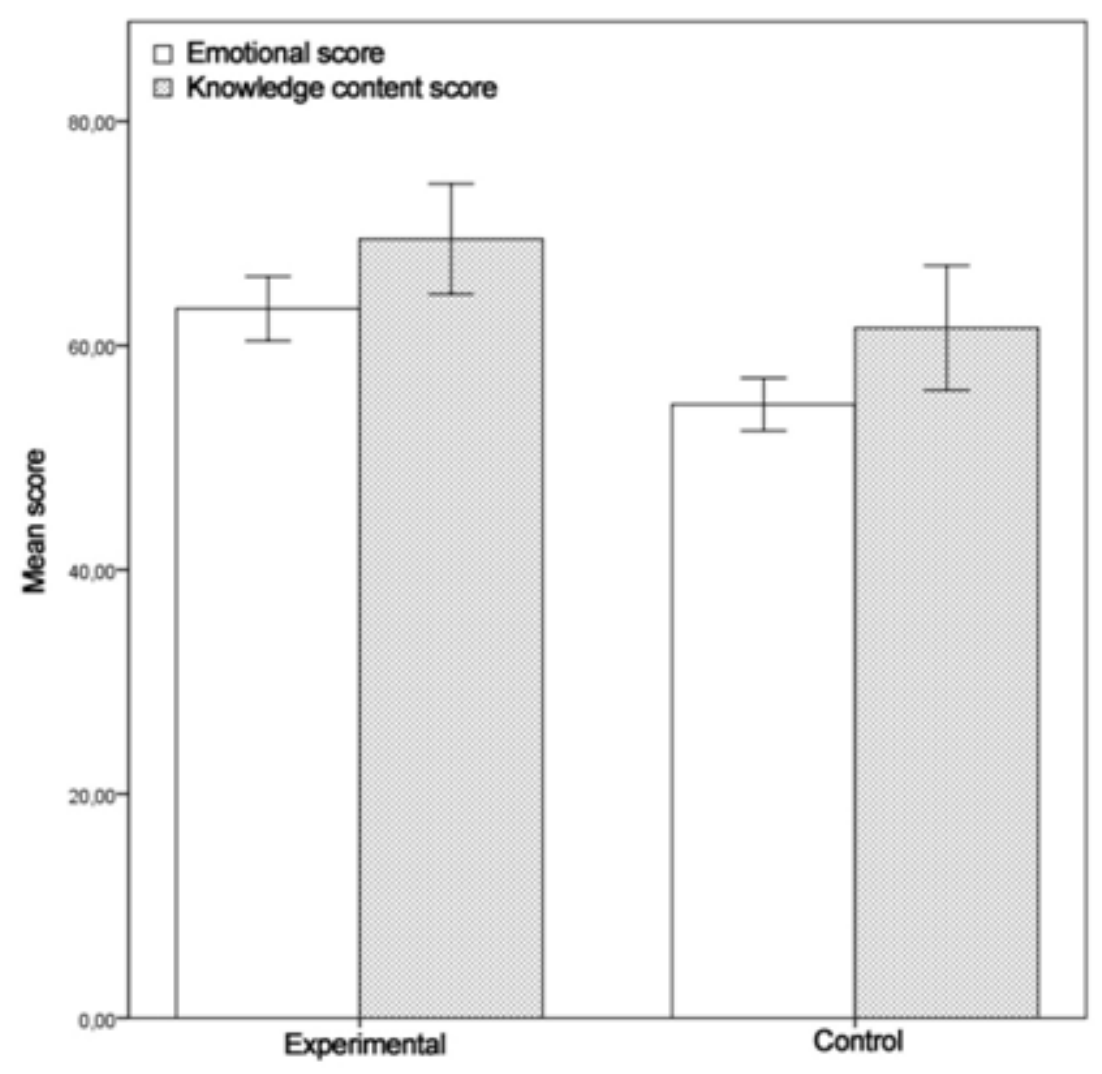

Figure 2. Mean score for emotional and knowledge content in posttest evaluation for Experimental and Control group. Confidence interval for error bars of $95 \%$

Figure 2 clearly depicts the emotional and cognitive performance. When compared blank columns and filled ones amongst them, error bars are clearly separated in the case of emotional score and slightly overlap in the case of content acquisition. The p-values confirmed the statistical significance of such results.

\subsection{Benefits of MIT-based teaching methodology for each specific IS}

Both instruction methodologies led to an enhancement of the emotional and cognitive score, and MIT-based instruction strategy also demonstrated to be more efficient in the teaching-learning process because the emotional yield and the knowledge acquisition were higher with this methodology than when the traditional one was used. The last step is to identify which kinds of IS are more favored with this change. 
Several studies have been carried out previously and aware about the need of putting special attention to some specific IS. E.g., there exists a clear coincident in placing those students with a prevalent Musical intelligence style in the last positions of the learning process in terms of emotional feelings. On the contrary, those students with Logical-Mathematical or Linguistic IS have been favored in terms of emotional and cognitive yield. This advantages may lay not only in the intrinsic nature of the Technology (what probably affects as well) but also in the instructional strategies the teachers implement in this subject, hence the importance of introducing new teaching activities.

Some authors have previously pointed out the adequacy of modelling the instructional strategies according to each student's actual IS in other science areas. For instance, Goodnough (2001) explores this in the context of an action-research group in the High School level and Karamustafaoglu (2010) performed a similar study on university students (prospective teachers) and both founded analogous results that encourage the individualization of the instruction method, as much as possible. In terms of Primary education, perhaps a good example of research (that also agrees with the two previous ones) is the work signed by Prieto, Ferrandiz and Ballester (2001) on the Spanish case.

We agree with Sánchez and Llera (2006) when they state the following:

There exist many few academic scoring systems that consider any other aspects beyond linguistic and logical ones.

Accordingly, Prieto et al. (2001) also stated:

Multiple Intelligences Theory uses neutral instruments regarding the intelligence. However, the large majority of psychometric tools are slant towards two Intelligence Styles: linguistic and logicalmathematical, so the students with these or a combination of both are always favored.

Consequently, we have analyzed the results of both Experimental and Control group according to the IS segmentation. The data set were globally not as large as it should be wished and because of that the statistical tests gave p-values not low enough. One has to take into account the fact that the whole study universe was subsequently divided into two main groups (Control and Experimental) and then, each one was divided again into 9 not balanced groups that corresponded to the 9 IS. This drove to a very low subject number. However, the results are clear enough for establishing a tendency, as can be seen in Table 2. 


\begin{tabular}{|c|c|c|c|c|c|c|}
\hline & \multicolumn{2}{|l|}{$\mathbf{N}$} & \multicolumn{2}{|c|}{ Meanscore } & & \\
\hline Intelligence Style & Experimental & Control & Experimental & Control & Levene's p-value & ANOVA p-value \\
\hline Linguistic & 8 & 13 & 61.75 & 55.23 & 0.819 & 0.111 \\
\hline Logical-mathematical & 4 & 5 & 74.50 & 58.40 & 0.258 & 0.153 \\
\hline Interpersonal & 14 & 14 & 64.42 & 54.64 & 0.098 & 0.09 \\
\hline Intrapersonal & 15 & 12 & 36.2 & 52.5 & 0.584 & 0.032 \\
\hline Environmental & 9 & 8 & 63.55 & 53.50 & 0.668 & 0.091 \\
\hline Spatial & 6 & 9 & 69.0 & 52.66 & 0.504 & 0.05 \\
\hline Bodily-kinesthesic & 16 & 6 & 60.8 & 60 & 0.537 & 0.877 \\
\hline Musical & 11 & 7 & 59.27 & 54.85 & 0.299 & 0.452 \\
\hline
\end{tabular}

Table 2. Emotional ANOVA post-test results segmented by Intelligence Styles

As can be shown, these numerical results clearly depict the fact that not every IS reacts in the same way when facing a new instruction methodology in terms of emotional performance. Levene's p-values for the 9 cases are above 0.05 , the significativity limit, so equal variances can be established for each comparison pair. However, as we said before, many ANOVA p-values are above 0.05 as well, hence the statistical taxative affirmation of our hypothesis cannot be done. Despite of it, the significativity levels for ANOVA are not long for this 0.05 and are even below it in the cases of Intrapersonal and Spatial IS, so the tendency can be appreciated with the exception of Bodily-kinesthetic IS, which gave a p-value for ANOVA too high (0.877). Every IS submitted a positive enhancement of the emotional score, being the most favored ones those subjects with Logical-mathematical (16.1 points of enhancement) and Spatial ones (16.34 points of enhancement). Further studies should be done for enlarging the study universe, so the results could be statistically confirmed. On the other hand, the least favored by this change of methodology were those with Bodily-kinesthetic IS, who only presented 0.8 points of enhancement. Graphically, Figure 3. 


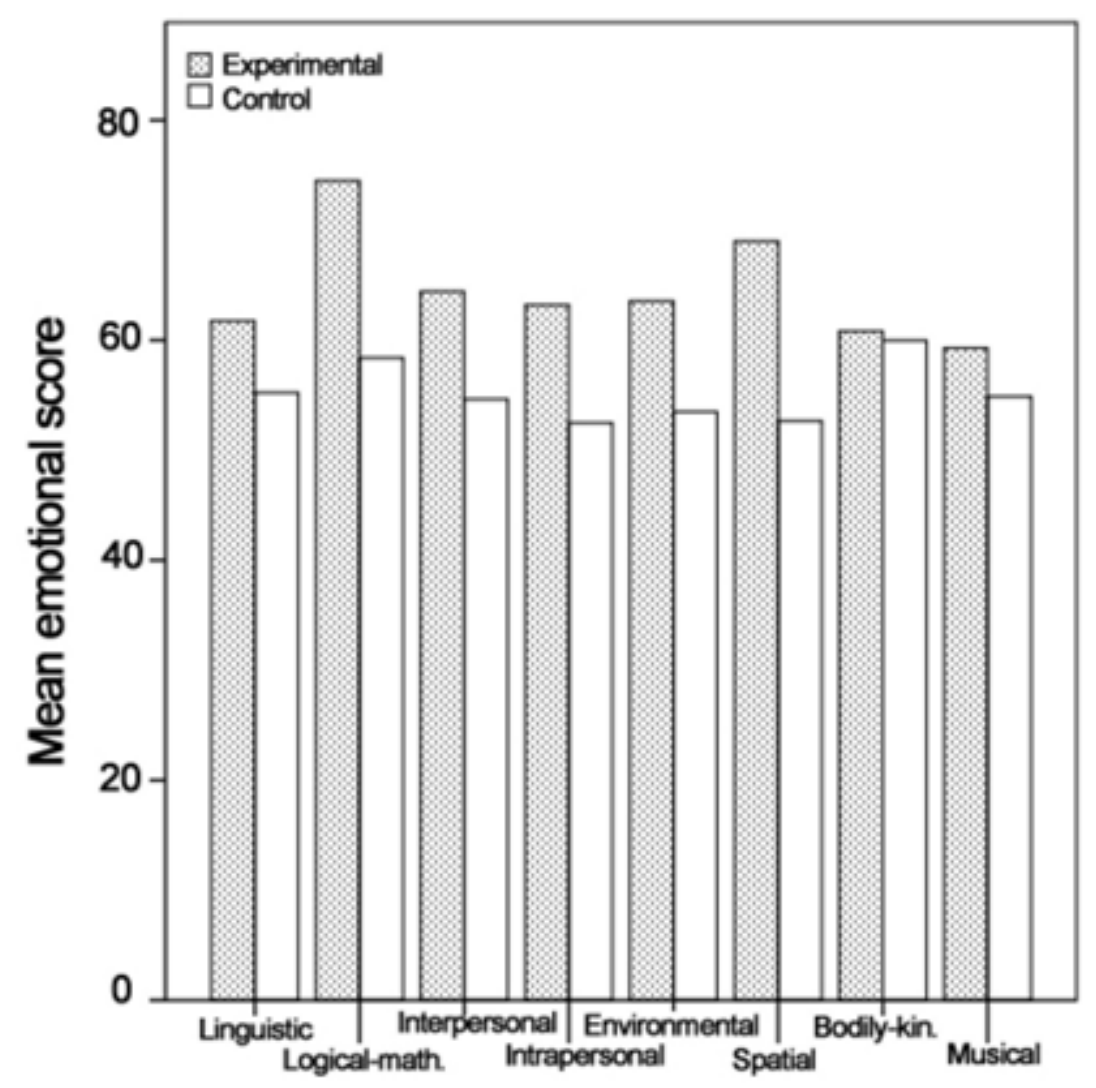

Figure 3. Mean score for emotional performance in post-test evaluation for Experimental and Control group segmented by IS.

Confidence interval for error bars of $95 \%$

In the case of knowledge content acquisition, the results are much more diffuse, as can be seen in Table 3. ANOVA p-values only reach the significativity limit for Interpersonal and Intrapersonal IS, being in the rest of the cases high enough not to be considered. However, the general tendency is again to present an enhancement in the content acquisition for almost every IS.

\begin{tabular}{|c|c|c|c|c|c|c|}
\hline & \multicolumn{2}{|l|}{$\mathbf{N}$} & \multicolumn{2}{|c|}{ Meanscore } & & \\
\hline Intelligence Style & Experimental & Control & Experimental & Control & Levene's p-value & ANOVA p-value \\
\hline Linguistic & 8 & 13 & 64.0 & 72.9 & 0.697 & 0.357 \\
\hline Logical-mathematical & 4 & 5 & 78.0 & 59.2 & 0.66 & 0.112 \\
\hline Interpersonal & 14 & 14 & 74.0 & 54.85 & 0.172 & 0.06 \\
\hline Intrapersonal & 15 & 12 & 72.26 & 51.66 & 0.533 & 0.049 \\
\hline Environmental & 9 & 8 & 68.0 & 59.0 & 0.89 & 0.374 \\
\hline Spatial & 6 & 9 & 79.53 & 74.66 & 0.754 & 0.65 \\
\hline Bodily-kinesthesic & 16 & 6 & 65.12 & 64.0 & 0.684 & 0.927 \\
\hline Musical & 11 & 7 & 63.18 & 56.57 & 0.034 & 0.564 \\
\hline
\end{tabular}

Table 3. Content acquisition ANOVA post-test results segmented by Intelligence Styles 


\section{Conclusions and some limitations}

Students reacts in different ways when they are subjected to a teaching-learning process and these emotional responses are different enough to take them into account and try to enhance them. This work has proven the benefits of including a specific attention to the Intelligence Styles when teaching circuitry. As it intrinsically happens with social sciences, it is very difficult to isolate a unique reason the intervention has actually worked with these students, which is evident from a statistical point of view. Perhaps the most accurate approach to the success of such intervention must involve not only the link with student motivation through a large variety of activities that surely is more attractive, but also the own teacher motivation. Whatever the reason is, it is clear that either the content acquisition and the emotional performance of the students subjected a statistically significant raise with this methodology. In it, every student was suggested to complete a list of 9 activities, one for each Intelligence Style. The statistical analysis of this educative instruction revealed that, compared with a control group, the students that carried out these activities reached higher emotional yield and their cognitive performance was also higher than those who followed the traditional transmission method. The results also depicted that, in terms of emotional performance, some Intelligence Styles are more favored by this methodology (Logical-mathematical and Spatial ones), while has almost null effect on Bodily-kinesthetic ones. These results should encourage teachers for paying special attention to Gardner's Multiple Intelligence Theory when scheduling their teaching activities, since a particular focus on each Intelligence Style enhances not only the emotional performance of the whole group, but also the content acquisition in the involved students.

\section{References}

Akkuzu, N., \& Akçay, H. (2011) The design of a learning environment based on the theory of multiple intelligence and the study its effectiveness on the achievements, attitudes and retention of students. Procedia Computer Science, 3(0), 1003-1008. https://doi.org/10.1016/j.procs.2010.12.165

Al-Balhan, E.H. (2006). Multiple Intellingences Styles in Relation to improved academic performance in Kuwaiti Middle School reading. Digest of Middle East Studies, 15(1), 18-34. https://doi.org/10.1111/j.1949-3606.2006.tb00002.x 
Almeida, L.S., Prieto, M.D., Ferreira, A.I., Bermejo, M.R., Ferrando, M., \& Ferrandiz, C. (2010). Intelligence assessment: Gardner multiple intelligence theory as an alternative. Learning and Individual Differences, 20(3), 225-230. https://doi.org/10.1016/j.lindif.2009.12.010

Álvarez, G.J., \& Canal, J.R. (2013) Perception of the student's emotions on Technology lessons in Secondary Obligatory Education (Percepción de las emociones en el alumnado de tecnología de Educación Secundaria Obligatoria). In: V. Mellado, L.J. Blanco, A.B. Borrachero \& J.A. Cárdenas (Eds.), Emotions in the Science and Mathematics teaching and learning process (Las emociones en la enseñanza y el aprendizaje de las ciencias y las matemáticas) (pp. 484-493). Badajoz: DEPROFE.

Álvarez-Gragera, G.J., Sánchez-Martín, J., Dávila-Acedo, M.A., \& Mellado, V. (2016). What do K12 students feel when dealing with Technology and Engineering issues? Gardner's Multiple Intelligences Theory implications in Technology lessons for motivating engineering vocations at Spanish Secondary School. In press.

Armstrong, T. (2009). Multiple Intelligences in the Classroom (3rd Edition). Alexandria, Virginia, USA: Association of Supervision and Curriculum Development.

Barrientos Jimenez, E., Mattza Díaz, I., Vildoso Villegas, J., \& Carola Sanchez, T. (2009). Multiple intellingences, learning styles and accomplishment level (Las Inteligencias múltiples, los estilos de aprendizaje y el nivel de rendimiento). Investigación Educativa, 13(23), 9-19.

Barrington, E. (2004). Teaching to student diversity Higher Education: How Multiple Intelligences Theory can help. Teaching in Higher Education, 9(4), 421-434.

https://doi.org/10.1080/1356251042000252363

Bisquerra, R. (2001). Emotional education and welfare (Educación emocional y bienestar). Barcelona: Wolters Kluwer.

Bisquerra, R. (2009). Emotions psychopedagogic (Psicopedagogía de las emociones). Madrid: Síntesis.

Black, P., \& Atkin, M. (2005). Changing the subject: Innovation in Science, Mathematics and Technology Education. London: OECD.

Borrachero, A.B., Brígido, M., Gomez, R., Bermejo, M.L., \& Mellado, V. (2011). Emotions in prospective secondary teachers on the science learning and teaching process (Las emociones de los futuros profesores de secundaria sobre el aprendizaje y la enseñanza de las ciencias). International Journal of Developmental and Educational Psicology, 23(2), 521-530. 
Brígido, M., Borrachero, A., Bermejo, M.L., \& Mellado, V. (2013). Prospective primary teachers’ self-efficacy and emotions in science teaching. European Journal of Teacher Education, 36(2), 200-217. https://doi.org/10.1080/02619768.2012.686993

Brígido, M., Couso, D., Gutiérrez, C., \& Mellado, V. (2013). The emotions about teaching and learning science: A study of prospective primary teachers in three Spanish universites. Journal of Baltic Science Education, 12(3), 299-311.

Chai, T.Y., Woo, S.S., Rizon, M., \& Tan, C.S. (2010). Classification of human emotions from EEG signals using statistical features and neural network. International Journal of Integrated Engineering (Isssue on Electrical and Electronic Engineering), 1(3), 1-6.

Choliz, M. (2005). Emotion psychology. The emotional process. Available online at: http://goo.gl/3ZBptJ

Conejo, R., Garcia-Vinas, J.I., Gaston, A., \& Barros, B. (2016). Technology-Enhanced Formative Assessment of Plant Identification. Journal of Science Education and Technology, 25(2), 1-19. https://doi.org/10.1007/s10956-015-9586-0

Damasio, A. (2010). And the brain created man (Y el cerebro creó al hombre). Barcelona: Destino.

Dos Santos, F.M.T., \& Mortimer, E.F. (2003). How emotions shape the relationship between a chemistry teacher and her high school students. International Journal of Science Education, 25(9), 1095-1110. https://doi.org/10.1080/0950069032000052216

Duit, R., Treagust, D.F., \& Widodo, A. (2008). Teaching science for conceptual change: theory and practice. In S. Vosniadou (Ed.), International handbook of research on conceptual change (pp. 629-646). New York: Routledge.

Fried, R.L. (2001). The passionate teacher. A practical guide. Boston, USA: Beacon Press.

Furnham, A. (2001). Self-estimates of intelligence: culture and gender difference in self and other estimates of both general (g) and multiple intelligences. Personality and Individual Differences, 31(8), 1381-1405. https://doi.org/10.1016/s0191-8869(00)00232-4

Furnham, A., Wytykowska, A., \& Petrides, K.V. (2005). Estimates of Multiple Intelligences: A Study in Poland. European Psychologist, 10(1), 51-59. https://doi.org/10.1027/1016-9040.10.1.51

Gardner, H. (1983a). Frames of Mind: The Theory of Multiple Intelligences. New York, USA: Basic Books. 
Gardner, H. (1983b). Multiple Intelligences: The Theory in Practice. New York, USA: Basic Books.

Gardner, H. (1989). Educational implications of the Theory of Multiple Intelligences. Educational Researcher, 18(8), 4-10. https://doi.org/10.3102/0013189x018008004

Gardner, H. (1991). Intelligence in seven steps. In D. Dickinson (Ed.), Creating the Future. Perspective on educational change (pp. 395-406). Washington DC: New Horizons for Learning.

Gardner, H. (1995). Reflections on multiple Intelligences: Myths and Messages. Phi Delta Capan, 77, 200-209.

Gianotti, F. (2015). There is no difference between arts and science. El Pais. Available online at: http://goo.gl/DoMZLI

Giorgis, N. (2007). Multiple Intelligences Profiles (Perfil de Inteligencias Múltiples). Electronic Bulletin 'Engineering First' (Boletín Electrónico “Ingeniería Primero”), 5.

Goleman, D. (1996). Emotional intelligence. new York: Bantam Books.

Goodnough, K. (2001). Multiple Intelligences Theory: A framework for personalizing science curricula. School Science and Mathematics, 1010(4), 180-193. https://doi.org/10.1111/j.19498594.2001.tb18021.x

Hargreaves, A. (1998). The emotions of teaching and educational change. In A. Hargreaves, M. Lieberman, M. Fullan \& D. Hopkins (Eds.), International handbook of educational change (pp. 558-575). Dordrecht, Boston, London: Kluwer Academic Publishers. https://doi.org/10.1007/97894-011-4944-0_28

Hill, A.M., \& Smith, H. (1998). Practice meets theory in Technology Education: A case of authentic learning in the High School Setting. Journal of Technology Education, 9(2), 29-45. https://doi.org/10.21061/jte.v9i2.a.3

Karamikabir, N. (2012). Gardner's Multiple Intelligence and Mathematics Education. Procedia Social and Behavioral Sciences, 31(0), 778-781. https://doi.org/10.1016/j.sbspro.2011.12.140

Karamustafaoglu, S. (2010). Evaluating the science activities based on Multiple Intelligences Theory. Journal of Turkish Science Education (TUSED), 7(1), 3-12.

Lewis, T. (2009). Creativity in technology education: providing children with glimpses of their inventive potential. International Journal of Technology and Design Education, 19(3), 255-268. ISSN 0957-7572. https://doi.org/10.1007/s10798-008-9051-y 
Li, M.C., \& Tsai, C.C. (2013). Game-based learning in science education: A review of relevant research. Journal of Science Education and Technology, 22(6), 877-898. https://doi.org/10.1007/s10956013-9436-x

Littledyke, M. (2008). Science education for environmental awareness: Approaches to integrating cognitive and affective domains. Environmental Education Research, 14(1), 1-17.

https://doi.org/10.1080/13504620701843301

Marbá-Tallada, A., \& Márquez, C. (2010). What do students think on Science lessons? A transversal study from Sixth Degree (Primary School) to Fourth Degree in Secondary Obligatory Education (¿Qué opinan los estudiantes de las clases de ciencias? Un estudio transversal de sexto de primaria a cuarto de ESO). Enseñanza de las ciencias, 28(1), 19-30.

McKenczie, W. (2005). Multiple Intelligences and instructional technology. Washington, D.C, USA.: ISTE Publications.

Otero, M.R. (2006). Emotions, feelings and reasoning in science education (Emociones, sentimientos y razonamientos en didáctica de las ciencias). Electronic Journal of Science Education (Revista electrónica en educación en ciencias), 1(1), 24-53.

Pintrich, P.R., Marx, R.W., \& Boyle, R.A. (1993). Beyond cold conceptual change: the role of motivational beliefs and classroom contextual factors in the process of conceptual change. Review of Educational Research, 63(2), 167-199. https://doi.org/10.3102/00346543063002167

Plutchik (2001). The nature of emotions, American Scientist, 89(4), 344-350.

Prieto, M.D., Ferrandiz, C., \& Ballester, P. (2001). Cognitive skill evaluation under the Multiple Intelligences Theory (Evaluación de la competencia cognitiva desde la teoría de las Inteligencias Múltiples). Enseñanza de las ciencias, 19, 91-111.

Sánchez, L.P., \& Llera, J.B. (2006). Two decades since "Multiple Intelligences Theory": Implications to Education Psychology (Dos décadas de Inteligencias Múltiples: Implicaciones para la psicología de la educación). Papeles del Psicólogo, 27(3), 147-164.

Shapiro, S. (2010). Revisiting the teachers' lounge: Reflections on emotional experience and teacher identity. Teaching and Teacher Education, 26(3), 616-621.

https://doi.org/10.1016/j.tate.2009.09.009

SPSS (2005). SPSS 14.0 Developer's guide. Chicago, Illinois: IBM. 
Straub, E.T. (2009). Understanding technology adoption: Theory and future directions for informal learning. Review of Educational Research, 79(2), 625-649.

https://doi.org/10.3102/0034654308325896

Sulaiman, T., Abdurahman, A.R., \& Rahim, S.S.A. (2010). Teaching Strategies Based on Multiple Intelligences Theory among Science and Mathematics Secondary School Teachers. Procedia Social and Behavioral Sciences, 8(0), 512-518. https://doi.org/10.1016/j.sbspro.2010.12.070

Thagard, P. (2009). Why Cognitive Science Needs Philosophy and Vice Versa. Topics in Cognitive Science, 1(2), 237-254. ISSN 1756-8765. https://doi.org/10.1111/j.1756-8765.2009.01016.x

Van Der Hoeven Kraft, K.J., Srogi, L., Husman, J., Semken, S., \& Fuhrmman, M (2011). Engaging students to learn through the affective domain: A new framework for teaching in the geosciences. Journal of Geoscience Education, 59(2), 71-84. https://doi.org/10.5408/1.3543934a

Vázquez, A., \& Manassero, M.A. (2007). In defense of attitudes and emotions in the scientific education (I): Evidences and general arguments (En defensa de las actitudes y emociones en la educación científica (I): Evidencias y argumentos generales). Eureka Journal of Science Education and Divulgation (Revista Eureka sobre Enseñanza y Divulgación de las Ciencias), 4(2), 247-271.

Weiner, B. (1986). An attributional theory of motivation and emotions. New York: Springer. https://doi.org/10.1007/978-1-4612-4948-1

Published by OmniaScience (www.omniascience.com)

Journal of Technology and Science Education, 2017 (www.jotse.org)

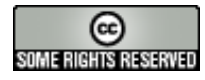

Article's contents are provided on an Attribution-Non Commercial 3.0 Creative commons license. Readers are allowed to copy, distribute and communicate article's contents, provided the author's and JOTSE journal's names are included. It must not be used for commercial purposes. To see the complete licence contents, please visit http://creativecommons.org/licenses/by-nc/3.0/es/ 